\title{
Genetic variation in a wild population of the 'sleep' passion fruit (Passiflora setacea) based on molecular markers
}

\author{
C.B.M. Cerqueira-Silva ${ }^{1,2}$, E.S.L. Santos ${ }^{1,2}$, L.D.H.C.S. Conceiçãa ${ }^{3}$, \\ C.B. Cardoso-Silva ${ }^{2}$, A.S. Pereira ${ }^{4}$, A.C. Oliveira ${ }^{5}$ and R.X. Corrêa ${ }^{4}$ \\ 'Departamento de Estudos Básicos e Instrumentais, \\ Universidade Estadual do Sudoeste da Bahia, Itapetinga, BA, Brasil \\ ${ }^{2}$ Instituto de Biologia, Universidade Estadual de Campinas, Campinas, \\ SP, Brasil \\ ${ }^{3} \mathrm{CPAC}$, Empresa Brasileira de Pesquisa Agropecuária, Brasília/Foraleza, \\ DF, Brasil \\ ${ }^{4}$ Departamento de Ciências Biológicas, Universidade Estadual de Santa Cruz, \\ Ilhéus, BA, Brasil \\ ${ }^{5}$ Departamento de Ciências Naturais, \\ Universidade Estadual do Sudoeste da Bahia, Vitória da Conquista, BA, Brasil \\ Corresponding author: C.B.M. Cerqueira-Silva \\ E-mail: csilva@uesb.edu.br
}

Genet. Mol. Res. 11 (1): 731-738 (2012)

Received May 16, 2011

Accepted September 22, 2011

Published March 22, 2012

DOI http://dx.doi.org/10.4238/2012.March.22.3

\begin{abstract}
Little is known about the molecular genetic diversity of most Passiflora species. We used RAPD markers to evaluate the genetic diversity of 24 genotypes of the 'sleep' passion fruit (Passiflora setacea). Twelve primers generated 95 markers, 88\% of which were polymorphic. The genetic distance estimated by the complement of the Dice index ranged from 0.29 (among accessions Ps-G1 and Ps-G13) to 0.69 (among accessions Ps-G21 and Ps-
\end{abstract}


G23). Genotype grouping based on the UPGMA algorithm showed considerable variability among genotypes. We conclude that $P$. setacea has a broad genetic base that could be exploited in breeding programs.

Key words: Similarity coefficient; Conservation; Genetic breeding; Genetic variability; Grouping analyses; Molecular marker

\section{INTRODUCTION}

The Passifloraceae family consists of about 18 genera and more than 580 species widely distributed in the tropics, although somewhat concentrated in Brazil, which is the birthplace of at least one third of these species (Ganga et al., 2004). For this reason Brazil is considered one of the main Passifloraceae diversity centers especially for the Passiflora genus (Faleiro et al., 2005).

Wild Passiflora species present potential for use in genetic breeding, exhibiting resistance to pests and diseases (Oliveira et al., 1994). These species also exhibit longevity, self-compatibility, better adaptation to adverse weather conditions, extended flowering period, shorter androgynophore, and higher concentration of chemical components of economic interest (Meletti et al., 2005; Junqueira et al., 2005).

Among the wild Passiflora with potential use in genetic improvement, the 'sleep' passion fruit (Passiflora setacea DC) deserves special attention due to its characteristics, which include sweet and tasty fruit, commonly used in fresh consumption and production of sweets (Sousa and Meletti, 1997). Moreover, the production of 'sleep' passion fruit accessions is not compromised by the occurrence of soil-borne pathogens that cause disease and early death (Menezes et al., 1994; Oliveira et al., 1994; Junqueira et al., 2005).

In this context, the 'sleep' passion fruit is an excellent source of genetic resistance to plant pathogens that attack the passion crops and can be used in breeding programs for commercial species such as 'yellow' passion fruit (Passiflora edulis Sims). The production of 'sleep' passion fruit is still limited to the extraction of plants in areas of occurrence, where they are sold on a small domestic scale. This type of activity is beginning to rise with the production of jams and jellies in processing industries located in the municipalities of Curaça, Uauá and Canudos in the State of Bahia (Araújo et al., 2006).

The characterization of genetic variability of wild populations of 'sleep' passion fruit contributes to the development of conservation strategies for the species, and supports the improvement of passion fruit culture. Faleiro et al. (2004) highlight the importance of knowledge about the genetic diversity of wild accessions through the potential applicability of this variability and of genotypes evaluated in breeding programs.

Specimens of 'sleep' passion fruit from the Embrapa Cerrados (Santos, 2006) and Active Collection of Passiflora Work Germplasm of the Universidade Estadual do Sudoeste da Bahia, Vitória da Conquista campus (CAGT-Passiflora/UESB 'Planalto de Conquista') (Cardoso-Silva et al., 2007) have been characterized in relation the physico-chemical quality of its fruits. However, there are no reports in the literature about molecular genetics characterization of cultivated or wild populations of 'sleep' passion fruit.

In molecular diversity characterizations, RAPD markers (random amplified poly- 
morphic DNA) (Williams et al., 1990) have been widely used in Passiflora species, such as P. alata (Bellon et al., 2005), P. edulis Sims (Bellon et al., 2007; Cerqueira-Silva et al., 2010a), P. trintae (Cerqueira-Silva et al., 2010b), and Passiflora spp (Viana et al., 2010).

We quantified, by RAPD markers and complement of the Dice index, the dissimilarity of wild genotypes of 'sleep' passion fruit, originating from the region of Vitória da Conquista, Bahia, Brazil, and belonging to the CAGT-Passiflora/UESB 'Planalto de Conquista'. The results are discussed in terms of characterization, conservation and breeding.

\section{MATERIAL AND METHODS}

We used 24 specimens of 'sleep' passion fruit (P. setacea) collected in fragments of a liana forest in Vitória da Conquista, Bahia State, Brazil (14 ${ }^{\circ} 53^{\prime} \mathrm{S}$ and $40^{\circ} 47^{\prime}$ 'W, elevation of $900 \mathrm{~m}$; average annual precipitation of 700-800 mm, concentrated between November and March, average annual temperature of $20-22^{\circ} \mathrm{C}$ ) (Instituto Nacional de Meteorologia/Ministério da Agricultura e Abastecimento), and belonging to the Active Collection of Passiflora Work Germplasm of the Universidade Estadual do Sudoeste da Bahia, Vitória da Conquista campus (CAGT-Passiflora/UESB 'Planalto de Conquista').

Leaf tissue samples of all genotypes were collected and stored in an ultra freezer $\left(-80^{\circ} \mathrm{C}\right)$ until DNA extraction, performed using the Doyle and Doyle protocol (1990). For the amplification reactions, standard procedures described for RAPD technique were adopted (Williams et al., 1990), using 12 Operon $^{\odot}$ Technologies primers (OPD-03, -05, -07, -11; OPE$07,-09,-11,-15,-16,-17,-18,-19)$. These primers were previously selected from 40 primers, since they identified a greater amount of molecular polymorphism and high genetic repeatability (data not shown).

The amplification products were separated by agarose gel electrophoresis $(1.6 \%)$, stained with ethidium bromide and submerged in 1X TBE (Tris-borate and EDTA buffer). The gels were photographed under ultraviolet light in the photo documentation system EDAS 290 (Kodak).

RAPD analysis was performed in duplicate and only patterns obtained clearly twice were scored. Presence or absence of fragments were recorded as 1 (present) or 0 (absent) and treated as binary characters. Resulting matrices of molecular data for all primers were submitted for analysis. Multivariate statistical procedures were carried out: i) estimation of the complement of genetic similarity $\left(\mathrm{dg}_{\mathrm{ij}}=1-\mathrm{sg}_{\mathrm{ij}}\right.$; where $d g_{i j}=$ dissimilarity and $s g_{i j}=$ similarity), through complement of the Dice coefficient (Dice, 1945); ii) genotypes clustering through the unweighted arithmetic average method (UPGMA), which was selected from among other hierarchical methods (Ward, Gower, complete linkage, single linkage), because it presents the smallest distortion and stress values and the largest values of cophenetic correlation (Cerqueira-Silva et al., 2009); iii) projection of the data in two-dimensional space, and iv) evaluation of the quality of the clustering and of the projection in two-dimensional space through distortion estimation, stress and correlation values.

For evaluating the efficiency of the clustering matrix and the projection of the data in a two-dimensional plane, the classification proposed by Kruskal et al. (1964) was used (Table 1). The statistical analyses were carried out with the assistance of the Genes software, Windows version (Cruz, 2006). 
Table 1. Stress classification for the goodness-of-fit of the graphic projection (Kruskal, 1964).

\begin{tabular}{ll}
\hline Stress level (\%) & Goodness-of-fit \\
\hline 40 & Unsatisfactory \\
20 & Regular \\
10 & Good \\
5 & Excellent \\
0 & Perfect \\
\hline
\end{tabular}

\section{RESULTS AND DISCUSSION}

The 12 primers used generated a total of 95 RAPD markers. A total of 84 polymorphic $(88 \%)$ and 11 monomorphic (12\%) markers were generated (an average of 7.9) (Table 2). These results exhibit a polymorphism higher than reported by Bellon et al. (2005), who worked with wild accessions of $P$. alata Curtis (62.1\% of polymorphic bands). The high average bands per primer are also evidence of high variability.

\begin{tabular}{|c|c|c|c|c|}
\hline Primers* & Sequence $\left(5^{\prime}-3^{\prime}\right)$ & No. of polymorphic bands & No. of monomorphic bands & No. of bands for primer \\
\hline OPD-03 & GTCGCCGTCA & 9 & 1 & 10 \\
\hline OPD-05 & TGAGCGGACA & 7 & 4 & 11 \\
\hline OPD-07 & TTGGCACGGG & 3 & 2 & 5 \\
\hline OPD-11 & AGCGCCATTG & 11 & 0 & 11 \\
\hline OPE-07 & AGATGCAGCC & 4 & 1 & 5 \\
\hline OPE-09 & CTTCACCCGA & 11 & 0 & 11 \\
\hline OPE-11 & GAGTCTCAGG & 4 & 0 & 4 \\
\hline OPE-15 & ACGCACAACC & 8 & 0 & 8 \\
\hline OPE-16 & GGTGACTGTG & 4 & 2 & 6 \\
\hline OPE-17 & CTACTGCCGT & 5 & 1 & 6 \\
\hline OPE-18 & GGACTGCAGA & 6 & 0 & 6 \\
\hline OPE-19 & ACGGCGTATG & 12 & 0 & 12 \\
\hline Total & & 84 & 11 & 95 \\
\hline
\end{tabular}

*Operon Technologies (http://www.operon.com).

In this context, several authors have observed variability in wild Passiflora. Bellon et al. (2005), who working with $P$. alata observed high variability (an average number of 12.05 bands per primer) and Cerqueira-Silva et al. (2010b), who working with $P$. tritae observed an average number of 7.46 bands per primer. With the commercial species $P$. edulis, Bellon et al. (2007) observed an average number of 14.4 bands per primer, while Cerqueira-Silva et al. (2010a) studying the same species observed a lower average number of bands per primer (5.7). Observing the results and data available in literature, the population characterized in the present study showed considerable variability, which can be exploited in future conservation and breeding studies.

The greatest genetic distance was observed among accessions Ps-G21 and Ps-G23 (0.69). In turn, the smallest distance was observed among accessions Ps-G1 and Ps-G13 (0.29) (Table 3). These values are higher than those found by Faleiro et al. (2004), who when comparing distinct accessions of P. nitida Kunth, observed genetic distance ranging from 0.08 to 0.43 . 


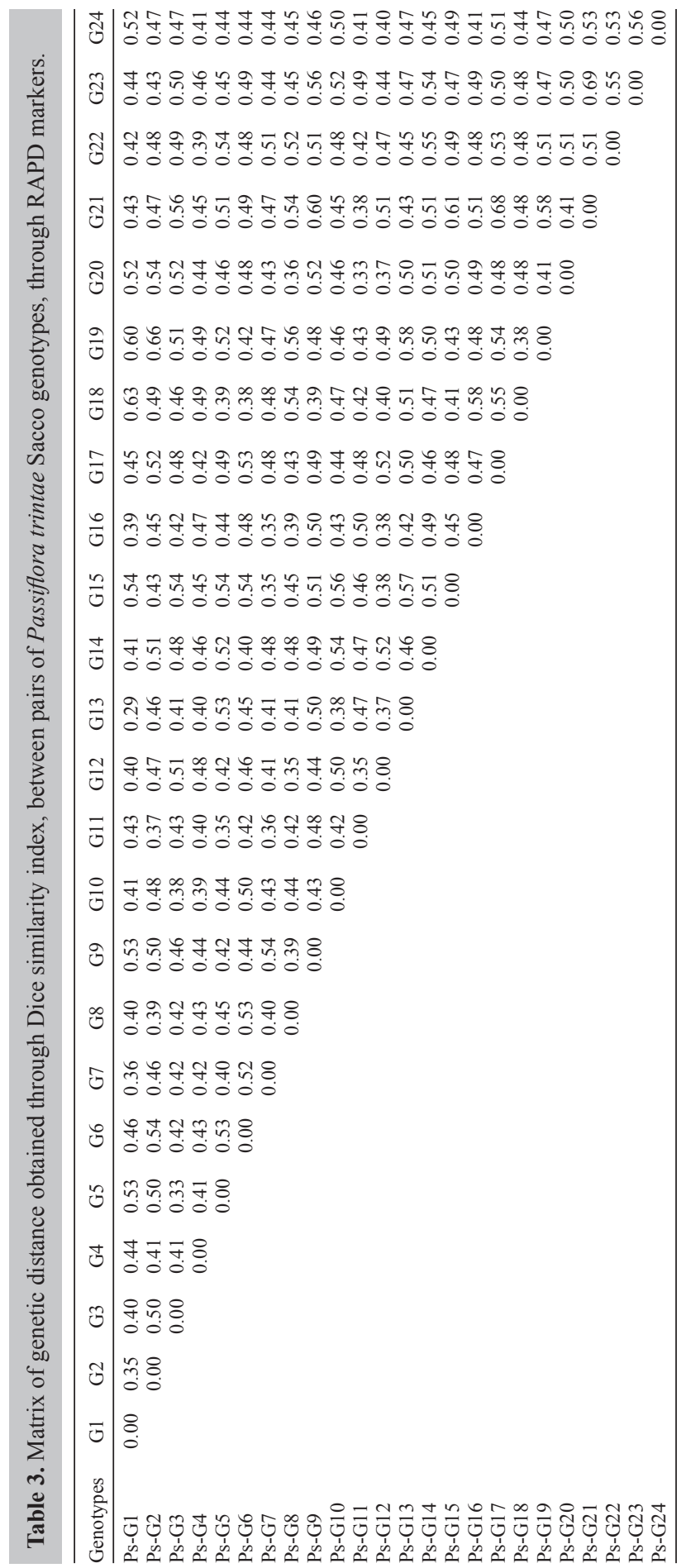


The association estimate between the original dissimilarity and grouping matrices presented values of 13.2, 0.44 and 12.8 for the parameters of distortion, cophenetic correlation and stress, respectively.

In turn, the projection of the distance data in a two-dimensional plane presented a high percentage of stress (70.3) and distortion (66.1) and low correlation value between the matrix of genetic dissimilarity and the graphical representation of projection (0.21) (Table 4). Based on the criterium proposed by Kruskal (Table 1) it is not advisable to present distance data in a two-dimensional plane, which justifies the representation of data through a dendogram (Figure 1). These results are consistent with the study of coefficients and comparison of distance measurements in passion fruit plants (Cerqueira-Silva et al., 2009).

Table 4. Efficiency of the clustering matrix and of the projection of the distances in the two-dimensional plane, from the diversity observed among Passiflora setacea DC genotypes through assessment of molecular polymorphism by the RAPD technique.

\begin{tabular}{lcc}
\hline Criteria & \multicolumn{2}{c}{ Viewing method } \\
\cline { 2 - 3 } & Grouping of genotypes & Projection of distances \\
\hline Distortion & 13.20 & 66.1 \\
Correlation* & 0.44 & 0.21 \\
Stress & 12.8 & 70.3 \\
\hline
\end{tabular}

*For the grouping of genotypes, the coefficient of cophenetic correlation was used, and for projection of distance correlation between the original distance and two-dimensional plane, distance was used.

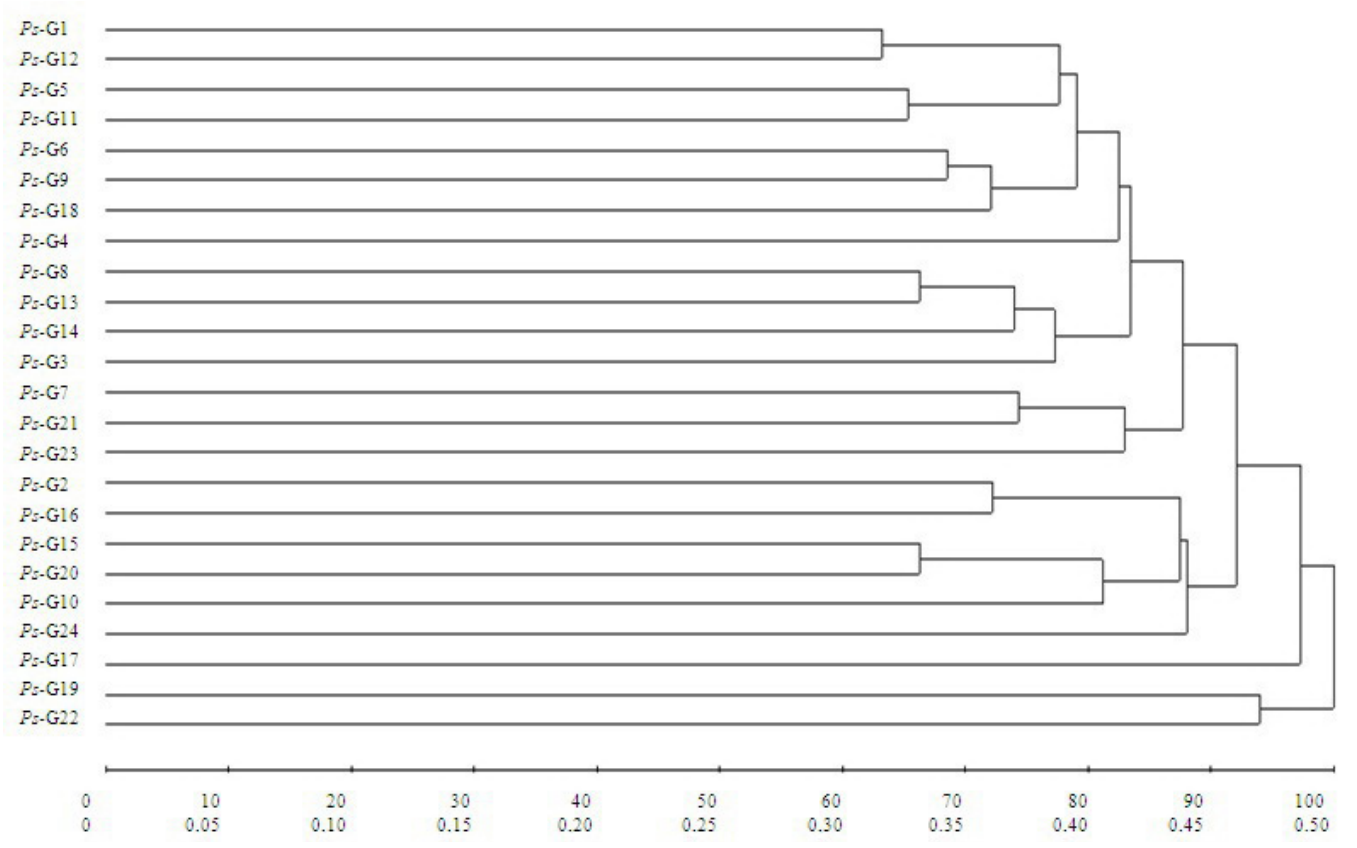

Figure 1. Clustering of 24 Passiflora setacea DC obtained through the clustering method based on the unweighted arithmetic average method (UPGMA) of distances estimated for the Dice-Sorenso coefficient from RAPD bands. $P S-\mathrm{G} 1$ to $P S-\mathrm{G} 24$ = genotypes evaluated. 
The great genetic variability among accessions of $P$. setacea DC makes clear the broad genetic basis of species, and good prospects for its use in breeding programs. Therefore, the information generated and the accessions characterized will be useful in future breeding programs aiming at the domestication of this species as well as the expansion of the genetic basis of resistance, especially with regard to the virus of hardening of fruits and resistance to drought and soil fungi.

\section{ACKNOWLEDGMENTS}

We would like to extend our thanks to Juliane dos Santos Amorim for her contribution during the laboratory phases. Research supported by CNPq and Programa de Pós-Graduação em Genética e Biologia Molecular of UESC, which approved this research as part of the Master's thesis dissertation for C.B.M. Cerqueira-Silva.

\section{REFERENCES}

Araújo FP, Silva N, Queiróz MA and Melo NF (2006). Estabelecimento de Acessos de Passiflora cincinnata Mast. por Organogênese Direta in vivo de Segmentos Radiculares. In: Encontro de Genética do Nordeste. Conhecimentos para o Novo Milênio, Sociedade Brasileira de Genética, Recife, 17.

Bellon G, Faleiro FG, Junqueira KP and Paula MS (2005). Diversidade Genética de Acessos Comerciais e Silvestres de Maracujazeiro-Doce com Base nos Marcadores RAPD. In: Reunião Técnica de Pesquisas em Maracujazeiro (Faleiro FG, Junqueira NTV and Braga MF, eds.). Embrapa Cerrados, Planaltina, 118-121.

Bellon G, Faleiro FG, Junqueira KP, Junqueira NTV, et al. (2007). Variabilidade Genética de Acessos Silvestres e Comerciais de Passiflora edulis Sims., com Base em Marcadores RAPD. Revista Brasileira de Fruticultura, Jaboticabal.

Cardoso-Silva CB, Melo JRF, Pereira AS and Cerqueira-Silva CBM (2007). Estudo da diversidade genética mediante caracterização fisico-química de frutos de maracujazeiros-do-sono nativos. Magistra 19: 352-358.

Cerqueira-Silva CB, Cardoso-Silva CB, Conceicao LD, Nonato JV, et al. (2009). Comparison of coefficients and distance measurements in passion fruit plants based on molecular markers and physicochemical descriptors. Genet. Mol. Res. 8: 870-879.

Cerqueira-Silva CBM, Conceição LDHCS, Cardoso-Silva CB and Pereira AS, et al. (2010a). Genetic diversity of yellow passion fruit (Passiflora edulis Sims.) based on RAPD markers. Crop Breed. Appl. Biotechnol. 10: 154-159.

Cerqueira-Silva CB, Cardoso-Silva CB, Santos ES, Conceicao LD, et al. (2010b). Genetic diversity in wild species of passion fruit (Passiflora trintae) based on molecular markers. Genet. Mol. Res. 9: 2123-2130.

Cruz CD (2006). Programa Genes: Aplicativo Computacional em Genética e Estatística. Editora UFV, Viçosa, 648.

Dice LR (1945). Measures of the amount of ecologic association between species. Ecology 26: 297-302.

Doyle JJ and Doyle JL (1990). Isolation of plant DNA from fresh tissue. Focus 12: 13-15.

Faleiro FG, Junqueira NTV, Bellon G, Borges TA, et al. (2004). Diversidade Genética de Espécies Silvestres de Maracujazeiro com Resistência a Múltiplas Doenças com Base em Marcadores RAPD. Fitopatol. Bras. 9: S325.

Faleiro FG, Junqueira NTV and Braga MF (2005). Germoplasma e Melhoramento Genético do Maracujazeiro- Desafios da Pesquisa. In: Maracujá: Germoplasma e Melhoramento Genético (Braga MF, Junqueira NTV and Braga MF, eds.). Embrapa Cerrados, Planaltina, 187-210.

Ganga RMD, Ruggiero C, Lemos EGM, Grili EGVG, et al. (2004). Diversidade genética em maracujazeiro-amarelo utilizando marcadores moleculares fAFLP. Rev. Bras. Frutic. 26: 494-498.

Junqueira NTV, Braga MF, Faleiro FG, Peixoto JR, et al. (2005). Potencial de Espécies Silvestres de Maracujazeiro como Fonte de Resistência a Doenças. In: Maracujá: Germoplasma e Melhoramento Genético (Faleiro FG, Junqueira NTV and Braga MF, eds.). Embrapa Cerrados, Planaltina, 81-107.

Kruskal JB (1964). Multidimensional scaling by optimizing goodness of fit to a nonmetric hypothesis. Psychometrika 29: $1-27$.

Meletti LMM, Soares-Scot MD, Bernacci LC and Passos IRS (2005). Melhoramento Genético do Maracujá: Passado e Futuro. In: Maracujá: Germoplasma e Melhoramento Genético (Faleiro FG, Junqueira NTV and Braga MF, eds.). Embrapa Cerrados, Planaltina, 55-78. 
Menezes JMT, Oliveira JC, Ruggiero C and Banzato DA (1994). Avaliação da taxa de pegamento de enxertos de maracujáamarelo sobre espécies tolerantes à "morte prematura de plantas". Cientifica 22: 95-104.

Oliveira JC, Nakamura K, Mauro AO and Centurion MAPC (1994). Aspectos Gerais do Melhoramento do Maracujazeiro. In: Maracujá: Produção e Mercado (São José AR, ed.). DFZ/UESB, Vitória da Conquista, 27-37.

Santos FC (2006). Caracterização Físico-Química do Fruto e Micropropagação do Maracujá-do-Sono (Passiflora setacea DC). Dissertação (Mestrado em Fitotecnia), Universidade Federal de Lavras, Lavras.

Sousa JSI and Meletti LMM (1997). Maracujá: Espécies, Variedades, Cultivo. FEALQ, Piracicaba.

Viana AJC, Souza MM, Araújo IS, Corrêa RX, et al. (2010). Genetic diversity in Passiflora species determined by morphological and molecular characteristics. Biol. Plant. 54: 535-538.

Williams JG, Kubelik AR, Livak KJ, Rafalski JA, et al. (1990). DNA polymorphisms amplified by arbitrary primers are useful as genetic markers. Nucleic Acids Res. 18: 6531-6535. 